\title{
ITERÁLT HARMADFOKÚ KVANTUMINFORMATIKAI PROTOKOLLOK
}

\author{
Portik Attila $^{1,2}$, Kálmán Orsolya ${ }^{2}$, Kiss Tamás $^{2}$ \\ ${ }^{1}$ Eötvös Loránd Tudományegyetem Természettudományi Kar, \\ 1117 Budapest, Pázmány Péter sétány 1/A \\ ${ }^{2}$ Wigner Fizikai Kutatóközpont, 1121 Budapest, Konkoly-Thege M. út 29-33.
}

DOI: https://doi.org/10.14232/kvantumelektronika.9.28

Egy olyan kvantuminformatikai protokollt vizsgálunk, amely egy összefonó unitér kapu, majd mérés és a mérés eredményén alapuló szelekció homogén kezdőállapotú qubit-sokaságon történő ismételt alkalmazásán alapul [1]. Az így létrejövő folyamat megfeleltethető egy komplex polinomok hányadosaként előálló komplex függvény iterált dinamikájának, ha a qubitet egy komplex számmal reprezentáljuk, ezért bizonyos kezdőfeltételek esetén kaotikus viselkedésre vezet [2]. Az ilyen nemlineáris folyamatoknak számos kvantuminformatikai alkalmazása lehet, mint például a kvantumállapotok tisztítása [3] vagy a kvantumállapot-megkülönböztetés [4,5,6]. Egy másik, érzékenységükön alapuló gyakorlati felhasználásuk lehet a kvantum-áramkörök, kvantum-chipek tesztelése, a fellépő zaj és hibaforrások feltérképezése.

Az általunk tekintett sémában a homogén kezdőállapotú qubit-sokaságból (amelyben a qubitek ugyanolyan állapotúak és egymástól függetlenek) hármasával veszünk elemeket, amelyeket egy unitér múvelettel összefonunk, majd a háromból két qubitet megmérünk. Ha a megmért qubiteket a kívánt állapotban találjuk, akkor a harmadik qubitet megtartjuk és rajta még egy további transzformációt végzünk (ellenkező esetben eldobjuk a harmadik qubitet is). A folyamatot az ilyen módon transzformált qubitekből képezett hármasokon tovább ismételjük, azaz iteráljuk.

Feltesszük tehát, hogy kezdetben van három független qubitünk, mindegyik ugyanabban a $\left|\psi_{0}\right\rangle=$ $N_{z}(|0\rangle+z|1\rangle)$ kezdeti állapotban, ahol $z \in \hat{\mathbb{C}}=\mathbb{C} \cup \infty$. Ekkor a teljes rendszer állapota:

$|\Psi\rangle=\left|\psi_{0}\right\rangle \otimes\left|\psi_{0}\right\rangle \otimes\left|\psi_{0}\right\rangle=N_{z}^{3}\left(|000\rangle+z|001\rangle+z|010\rangle+z^{2}|011\rangle+z|100\rangle+z^{2}|101\rangle+z^{2}|110\rangle+z^{3}|111\rangle\right)$.

A qubitek összefonását két controlled-NOT (CNOT) kapuval végezzük. A CNOT egy két-qubites múvelet, amely a kontroll qubit állapotától függően változtatja meg a cél-qubit állapotát: ha a kontrollqubit állapota $|1\rangle$, akkor a cél-qubit állapota ellenkezőre vált, ha a kontroll-qubit állapota $|0\rangle$, akkor a cél-qubit állapota nem változik meg. Közismert, hogy a CNOT operátor szorzatállapotokból összefonódottakat hoz létre. Ahhoz, hogy mindhárom qubitet összefonjuk, két CNOT múveletre van szükségünk. A mi esetünkben mindkét CNOT ugyanazt a qubitet használja kontrollként (legyen ez az elsố qubit), a cél qubitek pedig különböznek (egyik esetben a 2-es, a másikban a 3-as). Az említett két CNOT egymás utáni alkalmazásával létrejövő múveletet pedig úgy is felfoghatjuk, mint a CNOT transzformáció három qubitre általánosított verzióját, melynek a mátrix reprezentációja a következő- 
képpen adható meg:

$$
G_{\mathrm{CNOT}}=\left(\begin{array}{cccccccc}
1 & 0 & 0 & 0 & 0 & 0 & 0 & 0 \\
0 & 1 & 0 & 0 & 0 & 0 & 0 & 0 \\
0 & 0 & 1 & 0 & 0 & 0 & 0 & 0 \\
0 & 0 & 0 & 1 & 0 & 0 & 0 & 0 \\
0 & 0 & 0 & 0 & 0 & 0 & 0 & 1 \\
0 & 0 & 0 & 0 & 0 & 0 & 1 & 0 \\
0 & 0 & 0 & 0 & 0 & 1 & 0 & 0 \\
0 & 0 & 0 & 0 & 1 & 0 & 0 & 0
\end{array}\right),
$$

ahol a bázisvektorok sorrendjét $\{|000\rangle,|001\rangle,|010\rangle,|011\rangle,|100\rangle,|101\rangle,|110\rangle,|111\rangle\}$-nek vettuik. A három qubit állapota ezen transzformáció hatására a következőképpen változik meg:

$$
G_{\mathrm{CNOT}}|\Psi\rangle=N_{z}^{3}\left(|000\rangle+z|001\rangle+z|010\rangle+z^{2}|011\rangle+z^{3}|100\rangle+z^{2}|101\rangle+z^{2}|110\rangle+z|111\rangle\right) .
$$

Az általunk vizsgált sémában von Neumann méréseket tekintünk a 2-es és 3-as qubiten és az 1-es qubitet csak abban az esetben tartjuk meg, ha mindkét mérés eredménye 0 volt (ez természetesen csak bizonyos valószínúséggel valósul meg a konkrét mérések során). Ekkor a megtartott qubit állapota:

$$
\left|\psi^{\prime}\right\rangle=N_{z}^{\prime}\left(|0\rangle+z^{3}|1\rangle\right)
$$

A CNOT transzformációk és a méréseknek megfelelố szelekció elvégzése a $g: \hat{\mathbb{C}} \rightarrow \hat{\mathbb{C}}, g(z)=z^{3}$ komplex leképezésnek felel meg, amelynek ismételgetése egy diszkrét idejü determinisztikus nemlineáris dinamikára vezet, amely önmagában nem kifejezetten izgalmas. Ezért minden lépésben beiktatunk még egy egy-qubites unitér transzformációt, melyet a megtartott qubiteken hajtunk végre. Ezt az unitér transzformációt - az esetünkben érvényes szimmetria-tulajdonságokat is figyelembe véve a következőképpen paraméterezhetjük

$$
U(p)=\frac{1}{\sqrt{1+|p|^{2}}}\left(\begin{array}{cc}
1 & p \\
-\bar{p} & 1
\end{array}\right),
$$

ahol $p=\tan (\xi) e^{-i \varphi} \in \mathbb{C}$, és $\bar{p}$ a $p$ komplex konjugáltja. Ennek a múveletnek a beiktatása után a megtartott qubit állapota

$$
\left|\psi_{1}\right\rangle=N_{z}^{\prime \prime}\left(|0\rangle+\frac{z^{3}+p}{1-\bar{p} z^{3}}|1\rangle\right)
$$

lesz, így az iterációs lépést a következő komplex racionális törtfüggvény reprezentálja

$$
f_{p}(z)=\frac{z^{3}+p}{1-\bar{p} z^{3}}
$$

Ahhoz, hogy a kvantumrendszer viselkedését megismerjük elég ezt a komplex leképezést tanulmányoznunk. Az $f_{p}(z)$ függvény iterációja meglehetôsen összetett dinamikai viselkedést mutat, e dinamika néhány tulajdonságát mutatjuk itt be.

Az $f_{p}(z)$ leképezésnek négy fixpontja van, melyek meghatározásához az $f_{p}(z)=z$ egyenletet kell megoldani, ami a

$$
\bar{p} z^{4}+z^{3}-z+p=0
$$

komplex együtthatós negyedfokú polinom-egyenletre vezet, amelynek négy komplex megoldása van általános $p$ esetén. A függvény $f_{p}^{\prime}(z)$ deriváltjának a $z_{0}$ fixpontban felvett értéke alapján a fixpont lehet semleges $\left(\left|f_{p}^{\prime}\left(z_{0}\right)\right|=1\right)$, taszító $\left(\left|f_{p}^{\prime}\left(z_{0}\right)\right|>1\right)$, vagy vonzó $\left(\left|f_{p}^{\prime}\left(z_{0}\right)\right|<1\right)$, esetleg szupervonzó 


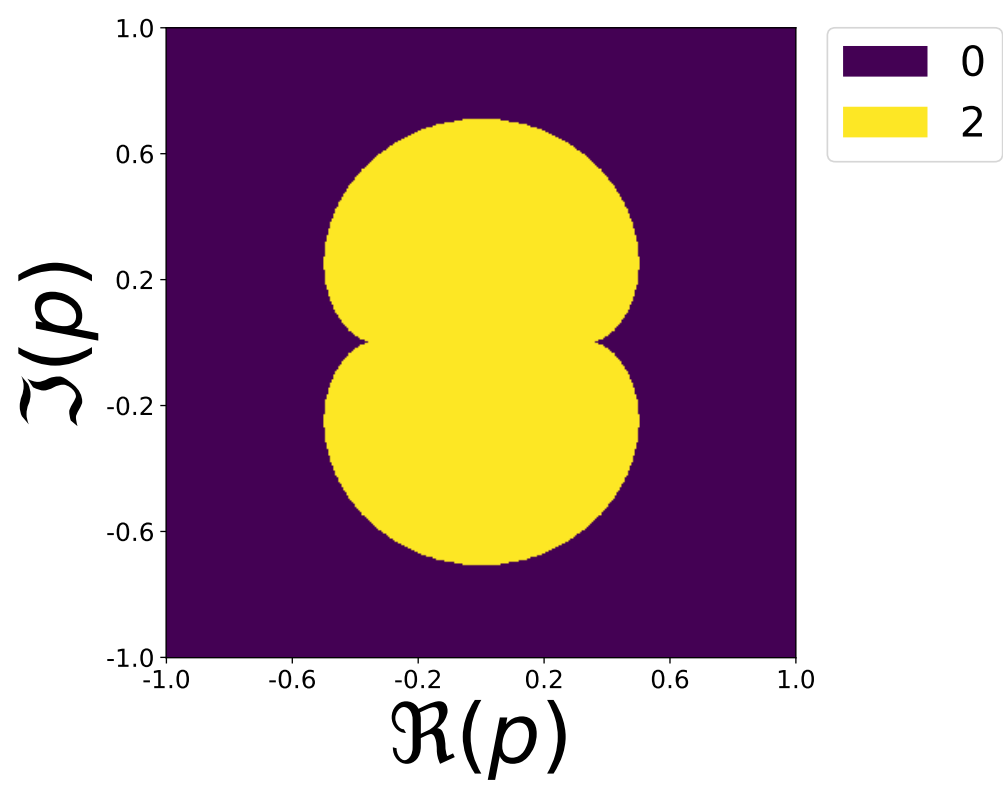

1. ábra. A $p$ paramétertér origó körüli részének a szerkezete a $p$ paraméterrel jellemzett $f_{p}$ leképezés vonzó fixpontjainak száma szerint. Sárga szín jelöli azokat a paramétereket, amelyek esetén a leképezésnek két vonzó fixpontja van és lila azokat, amelyek esetén a leképezésnek nincs vonzó fixpontja. Az ábra elkészítéséhez 2500 × 2500-as felosztást használtunk.

$\left(\left|f_{p}^{\prime}\left(z_{0}\right)\right|=0\right)$. Egy iterált racionális komplex polinomfüggvényekre vonatkozó tétel szerint maximum 4 vonzó fixpontot vagy fix ciklust találhatunk.

Megvizsgáltuk, hogy a $p$ paraméter különböző értékeihez tartozó, (1) egyenletben megadott $f_{p}$ leképezéseknek hány vonzó fixpontja van. Ehhez numerikus szimulációt végeztünk, amelynek során kijelöltünk egy véges tartományt a paramétertérből, ennek vettük egy alkalmas felosztását, az egyes $p$ értékek esetén megkerestük a fixpontokat, majd kiértékeltük a függvény deriváltját az adott fixpontokban. Az így kapott eredményeket az 1. ábra mutatja. A paramétertér tükörszimmetriát mutat mind a valós mind a képzetes tengelyre. A két vonzó fixponttal rendelkező leképezéseknek megfelelő tartományt körülöleli az, amely esetén a fixpontok közül egy sem vonzó (utóbbi térrészben természetesen létezhetnek hosszabb vonzó ciklusok). Megjegyezzük, hogy minden $p$-re vagy 0 vagy 2 fixpontot találtunk.

Egy adott $p$ paraméterrel jellemzett $f_{p}(z)$ függvény iterálása nyomán a $z$ állapottéren két (egymást kiegészítő) halmazt különböztethetünk meg. Az ún. Fatou-halmaz azon pontokat tartalmazza, melyek közül a kezdetben egymáshoz közeliek több iteráció után is közel maradnak és konvergálnak a leképezés valamely vonzó ciklusához. Ezzel szemben az ún. Julia-halmaz elemei olyan pontok, melyek nem tartanak egyik vonzó ciklushoz sem, és a kezdőállapot tetszőlegesen kicsiny perturbációja is drasztikusan különböző állapotra vezethet az iterációs lépések során. A Julia-halmaz tehát az instabil pontokat tartalmazza, melyek kaotikusan viselkednek. A kaotikus viselkedést jellemezhetjük az ún. Ljapunov-exponenssel, amely a kezdetben közeli fázistérbeli pontok egymástól való exponenciális eltávolodását írja le. Ha az értéke pozitív, az a rendszerbeli valódi kaotikus viselkedés megjelenését jelenti.

A z pontbeli Ljapunov-exponenst a következő kifejezéssel definiálhatjuk [7]:

$$
\begin{aligned}
L(z)=\lim _{n \rightarrow \infty} \frac{1}{n} \ln \left(\left|f^{\prime}(z)\right|_{R} \cdot\left|f^{\prime}(f(z))\right|_{R} \cdot\left|f^{\prime}\left(f^{\circ 2}(z)\right)\right|_{R}\right. & \left.\cdots\left|f^{\prime}\left(f^{\circ n-1}(z)\right)\right|_{R}\right) \\
& =\lim _{n \rightarrow \infty} \frac{1}{n} \ln \left(\prod_{k=0}^{n-1}\left|f^{\prime}\left(f^{\circ n-1}(z)\right)\right|\right) .
\end{aligned}
$$


Itt $f^{\circ n}(z)$ az $f(z)$ függvény $n$-edik iteráltját, $|\cdot|_{R}$ pedig a Riemann-gömbön mért távolságot jelöli a Riemann-gömb déli pólusától, mely adott $z$-re $|z|_{R}=2|z| / \sqrt{|z|^{2}+1}$.

A Julia-halmazon megjelenô káoszt és a pozitív Ljapunov-exponens megjelenését úgy vizsgáltuk, hogy az adott $p$ paraméterrel jellemzett $f_{p}(z)$ leképezést numerikusan iterálva közelítettük a (2) egyenletet. Az eredményt a $p=i$ paraméternek megfelelő esetben a 2. ábra mutatja, melyen megfigyelhetô, hogy az exponens egy fraktál alakzat mentén vesz fel pozitív értéket, ez a halmaz a leképezés Julia-halmaza. Ellenőrizhető, hogy azokban a tartományokban, ahol a Ljapunov-exponens negatív, a kezdőállapotok két 2-hosszú stabil vonzó ciklushoz tartanak (Fatou-halmaz).
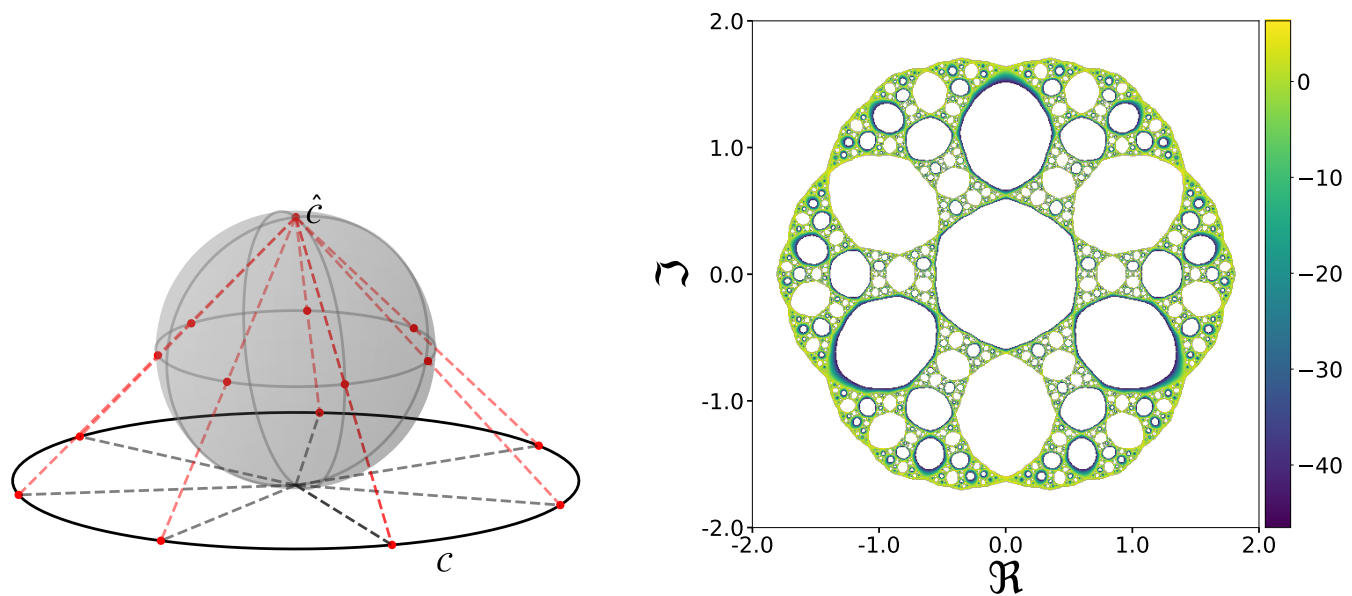

2. ábra. (Bal oldal) A $\mathbb{C}$ és $\widehat{\mathbb{C}}$ közötti megfeleltetés a komplex számgömb és az azt egy pontban érintő komplex számsík közötti sztereografikus leképezéssel adható meg. A sztereografikus leképezés során a gömb síkkal való érintkezési pontjával átellenes pontjából induló félegyenesek által a síkból kimetszett $z \in \mathbb{C}$ pontot és a gömbből kimetszett $z^{\prime} \in \hat{\mathbb{C}}$ megfeleltetjük egymásnak. Ekkor a 0 és a $\infty$ pontok rendre az érintkezési pontnak és az azzal átellenes pontnak felelnek meg. (Jobb oldal) A $p=i$ paraméterhez tartozó leképezés fázistere a numerikusan közelített Ljapunov-exponens értéke szerint kiszínezve. A vonzó ciklusok vonzási tartományai nincsenek kiszínezve.

Összefoglalva, az iterált harmadfokú nemlineáris protokoll bemutatott tulajdonságai alapvetően hasonlítanak a másodfokú esethez (ott a $p=1$ paraméterértéket véve), azonban a 2. ábrán bemutatott fraktál szimmetriája megváltozott: négyfogásos helyett hatfogásossá vált. A teljes $p$ paramétertér feltérképezésével várhatóan még jobban megérthetjük majd a harmadfokú dinamika sajátosságait és a másodfokútól eltérô tulajdonságait. Ez kulcsfontosságú lehet a protokoll alkalmazása szempontjából.

\section{Köszönetnyilvánítás}

A kutatást az Innovációs és Technológiai Minisztérium és a Nemzeti Kutatási, Fejlesztési és Innovációs Hivatal támogatta a Kvantuminformatika Nemzeti Laboratórium, a K124351 sz. és a 2017 1.2.1-NKP-2017-00001 sz. projekt keretében.

\section{Irodalom}

[1] T. Kiss, I. Jex, G. Alber and S. Vymětal, Phys. Rev. A 74, 040301(R) (2006). https://doi.org/10.1103/PhysRevA.74.040301

[2] A. Gilyén, T. Kiss and I. Jex, Sci. Rep. 6, 20076 (2016). https://doi.org/10.1038/srep20076 
[3] T. Kiss, S. Vymětal, L. D. Tóth, A. Gábris, I. Jex and G. Alber, Phys. Rev. Lett. 107, 100501 (2011). https://doi.org/10.1103/PhysRevLett.107.100501

[4] J. M. Torres, J. Z. Bernád, G. Alber, O. Kálmán and T. Kiss, Phys. Rev. A 95, 023828 (2017). https://doi.org/10.1103/PhysRevA.95.023828

[5] O. Kálmán and T. Kiss, Phys. Rev. A 97, 032125 (2018). https://doi.org/10.1103/PhysRevA.97.032125

[6] G. Zhu O. Kálmán, K. Wang, L. Xiao, D. Qu, X. Zhan, Z. Bian, T. Kiss, and P. Xue, Phys. Rev. A 100, 052307 (2019). https://doi.org/10.1103/PhysRevA.100.052307

[7] A. Gilyén, Egy qubites káosz és kapcsolata a komplex dinamikus rendszerekhez (TDK dolgozat, 2013). 